\title{
Involvement of estrogen receptor- $\beta$ in farrerol inhibition of rat thoracic aorta vascular smooth muscle cell proliferation
}

\author{
Qun-yi LI ${ }^{1, \#, ~ §, ~ L i ~ C H E N ~}{ }^{2, \#, ~ đ I ~, ~ Y a n-h u i ~ Z H U ~}{ }^{1}$, Meng ZHANG ${ }^{1}$, Yi-ping WANG ${ }^{2}$, Ming-wei WANG ${ }^{1,2, *}$ \\ ${ }^{1}$ The National Center for Drug Screening and ${ }^{2}$ the State Key Laboratory of New Drug Research, Shanghai Institute of Materia Medica, \\ Chinese Academy of Sciences, Shanghai 201203, China
}

Aim: To investigate the effect of farrerol, a major active component isolated from a traditional Chinese herb "Man-shan-hong" (the dried leaves of Rhododendron dauricum $\mathrm{L}$ ) on fetal bovine serum (FBS)-induced proliferation of cultured vascular smooth muscle cells (VSMCs) of rat thoracic aorta.

Methods: VSMCs proliferation, DNA synthesis and cell cycle progression were studied using the MTT assay, bromodeoxyuridine (BrdU) incorporation and flow cytometry, respectively. The mRNA levels of cell cycle proteins were quantified using real-time RT-PCR, and the phosphorylation of ERK1/2 was determined using Western blotting. Reporter gene and receptor binding assays were employed to study the interaction between farrerol and estrogen receptors (ERs).

Results: Farrerol (0.3-10 $\mu \mathrm{mol} / \mathrm{L})$ inhibited VSMC proliferation and DNA synthesis induced by $5 \%$ FBS in a concentration-dependent manner. The effects were associated with $\mathrm{G}_{1}$ cell cycle arrest, down-regulation of cell cycle proteins and reduction in FBS-induced ERK1/2 phosphorylation. Using a reporter gene, it was found that farrerol (3 $\mu \mathrm{mol} / \mathrm{L})$ induced 2.1-fold transcription of ER. In receptor binding assays, farrerol inhibited the binding of $\left[{ }^{3} \mathrm{H}\right]$ estradiol for ER $\alpha$ and ER $\beta$ with $\mathrm{IC}_{50}$ values of $57 \mu \mathrm{mol} / \mathrm{L}$ and $2.7 \mu \mathrm{mol} / \mathrm{L}$, respectively, implying that farrerol had a higher affinity for ERß. Finally, the inhibition of VSMC proliferation by farrerol ( $3 \mu \mathrm{mol} / \mathrm{L}) \mathrm{was}$ abolished by the specific ERß antagonist PHTPP (5 $\mu \mathrm{mol} / \mathrm{L})$.

Conclusion: Farrerol acts as a functional phytoestrogen to inhibit FBS-induced VSMC proliferation, mainly via interaction with ERß, which may be helpful in the treatment of cardiovascular diseases related to abnormal VSMCs proliferation.

Keywords: farrerol; phytoestrogen; estrogen receptor; vascular smooth muscle cells; cell proliferation; cell cycle; ERK1/2; receptor binding assay

Acta Pharmacologica Sinica (2011) 32: 433-440; doi: 10.1038/aps.2011.1; published online 14 Mar 2011

\section{Introduction}

Abnormal proliferation of vascular smooth muscle cells (VSMCs) plays a critical role in intimal formation in the early stage of atherosclerosis and restenosis ${ }^{[1]}$. Several reports have indicated that reduction of VSMC proliferation using therapeutic agents ( $\mathrm{eg}$, estrogen) would give rise to vasoprotective effects $^{[2]}$. Estrogen exhibits a variety of actions on the vascular wall that could be implicated in its athero-protective properties $^{[3]}$. These include, but are not limited to, the inhibition of

\footnotetext{
\#These two authors contributed equally to this work.

${ }^{\S}$ Now in Clinical Pharmacy Laboratory, Huashan Hospital, Fudan University, Shanghai 200040, China.

${ }^{9}$ Now in Department of Preventive Medicine, Tongji University School of Medicine, Shanghai 200092, China.

*To whom correspondence should be addressed.

E-mail wangmw@mail.shcnc.ac.cn

Received 2010-09-02 Accepted 2011-01-05
}

VSMC proliferation $^{[4,5]}$.

As we know, earlier studies supported the widespread belief in the hypothesis of cardiovascular benefit of hormone replacement therapy (HRT) in postmenopausal women, but recent Women's Health Initiative (WHI) trials found no coronary heart disease (CHD) benefit among women aged 50 to 79 and HRT increased risk of stroke ${ }^{[6,7]}$. However, WHI also provided evidence that CHD risks are reasonably low for short-term use by younger postmenopausal women ${ }^{[8,9]}$. Although "timing hypothesis" and "critical window theory" for estrogen intervention in preventing atherosclerosis were developed, there is still a need to better understand the relationship between circulating estrogen levels and aging of the cardiovascular system.

It has been suggested that steroidal hormones used in HRT may lead to unacceptable adverse effects such as carcinogenicity in the endometrium ${ }^{[10]}$. Tamoxifen and raloxifene ${ }^{[11,12]}$, the 
nonsteroidal and selective estrogen receptor modulators, have shown cardioprotective benefits with reduced side effects, indicating that alternative estrogen-like agents may possess better therapeutic index. Therefore, interests have been directed to phytoestrogens derived from natural products, especially isoflavones present in soya beans ${ }^{[13]}$. An increasing number of studies suggest that some phytoestrogens could be promising substitutes for estrogen in preventing cardiovascular diseases through inhibiting VSMC proliferation and migration $^{[14-16]}$.

The flavonoid farrerol (Figure 1) is abundant in a traditional Chinese herb "Man-shan-hong", the dried leaves of Rhododendron dauricum $\mathrm{L}$. It is considered to be the main bioactive ingredient of this plant and has been used as an antibechic in China ${ }^{[17]}$. In recent years, farrerol has attracted considerable interests due to its anti-inflammatory, antibacterial, and antioxidant activities exerted via scavenging radicals and inhibiting a variety of enzymes ${ }^{[18,19]}$. However, to our knowledge, the effects of farrerol on cardiovascular system have not been reported to date. In view of the structural similarities between farrerol and estrogenic isoflavones (eg, genistein and daidzein), it would be tempting to learn if farrerol could act as a phytoestrogen in VSMCs. Thus, this study was designed and carried out to investigate the impact of farrerol on VSMC proliferation and its interaction with estrogen receptors.

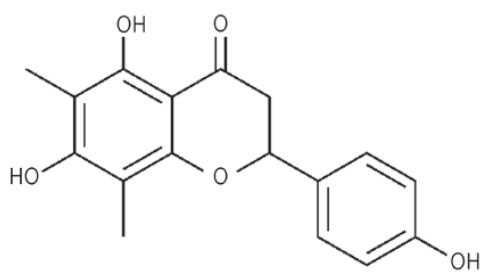

Figure 1. Chemical structure of farrerol.

\section{Materials and methods Reagents}

Farrerol is a reference compound (purity $\geq 99.0 \%$ ) supplied by the Division of Chinese Materia Medica and Natural Products, National Institute for the Control of Pharmaceutical and Biological Products (NICPBP), Ministry of Health, China. $\beta$-Estradiol 17-acetate $\left(\mathrm{E}_{2}\right)$, methyl-piperidino-pyrazole (MPP), 4-[2-[phenyl-5,7-bis(trifluoromethyl)pyrazolo[1,5-a]pyrimidin-3-yl]phenol (PHTPP), ICI182,780, BrdU, and 2,3-bis(4hydroxyphenyl)-propionitrile (DPN) were obtained from Sigma (St Louis, MO, USA). Polyclonal anti- $\beta$-actin, monoclonal anti-phospho-ERK1/2 and polyclonal anti-ERK1/2 antibodies were purchased from Santa Cruz Biotechnology (Santa Cruz, CA, USA). Polyclonal antibodies to ERa and ER $\beta$ were procured from Abcam Inc (Cambridge, MA, USA).

\section{Cell culture}

Primary VSMCs were obtained from the thoracic aorta of 3-month old female Sprague-Dawley rats using the tissue explant method described elsewhere ${ }^{[20]}$. More than $98 \%$ of the cells were positive for staining with smooth muscle-specific a-actin, and exhibited the typical hill-and-valley morphology of VSMCs. Cells between passages 2 and 5 were used in this study to ensure the genetic stability of the culture. Cells grown to $80 \%-95 \%$ confluence were made quiescent by starvation $(0.1 \% \mathrm{FBS})$ for $24 \mathrm{~h}$.

\section{Cell proliferation}

The cell proliferation assay was performed using the MTT [3-(4,5-dimethylthiazol-2-yl)-2,5-diphenyltetrazolium bromide] method. Briefly, growth-arrested VSMCs were incubated with or without farrerol for $2 \mathrm{~h}$ prior to stimulation with 5\% FBS for $48 \mathrm{~h}$. They were then incubated with 0.5 $\mathrm{mg} / \mathrm{mL}$ MTT for $4 \mathrm{~h}$ at $37^{\circ} \mathrm{C}$. Finally, the culture medium was removed and the formazan salt crystals was dissolved with $200 \mu \mathrm{L}$ dimethylsulfoxide (DMSO) followed by shaking at room temperature for $10 \mathrm{~min}$. The absorbance was read at a wavelength of $570 \mathrm{~nm}$ using a Spectramax M2 microplate reader (Molecular Devices, Sunnyvale, CA, USA).

\section{BrdU incorporation}

DNA synthesis in VSMCs was examined using the BrdU incorporation assay previously described ${ }^{[21]}$. Quiescent VSMCs were treated with or without farrerol for $2 \mathrm{~h}$ prior to stimulation with 5\% FBS for $24 \mathrm{~h}$. For inhibition experiments, cells were pretreated with MPP or PHTPP for 30 min before addition of farrerol or DMSO.

Subsequently, $10 \mu \mathrm{mol} / \mathrm{L} \mathrm{BrdU}$ was added to the cells and incubated for additional $24 \mathrm{~h}$. To immunostain BrdU, the cells were washed with PBS, fixed in $4 \%$ polyformaldehyde and permeabilized with $0.1 \%$ Triton X-100. After DNA denaturation with $4 \mathrm{~mol} / \mathrm{L} \mathrm{HCl}$, non-specific binding sites were blocked with $5 \%$ non-fat milk. The cells were then stained with an antibody to BrdU (Invitrogen, Carlsbad, CA, USA) followed by incubation with Alexa Flour 568 labeled goat antimouse IgG (Invitrogen) secondary antibodies. The cell nuclei were stained with Hoechst 33342 and evaluated by fluorescence microscopy with appropriate fluorescent filters. Results are presented as mitotic index, and defined as the percentage of BrdU-positive nuclei observed in a cell population.

\section{Flow cytometry}

Quiescent VSMCs were preincubated with or without farrerol for $2 \mathrm{~h}$, followed by 5\% FBS treatment for $24 \mathrm{~h}$. They were then trypsinized, collected, and washed twice with cold PBS. Cell pellets were fixed in $70 \%$ ethanol and stored at $4{ }^{\circ} \mathrm{C}$ until use. The fixed cells were reacted with RNase A $(10 \mu \mathrm{g} / \mathrm{mL})$, DNA was stained with propidium iodide $(50 \mu \mathrm{g} / \mathrm{mL})$ for 30 min at $37^{\circ} \mathrm{C}$, and $1 \times 10^{4}$ cells were analyzed by flow cytometry. The rates of $G_{0} / G_{1}, S$, and $G_{2} / M$ phases were determined using the software program ModiFit LT (BD, Franklin Lakes, NJ, USA).

\section{Quantitative real-time PCR}

Total RNA from VSMCs was extracted with the TRIzol reagent 
(Invitrogen) and reverse transcribed (RT) using Superscript II First-strand Synthesis SuperMix (Invitrogen). Primers and real-time PCR conditions were described previously ${ }^{[22,23]}$ : $\beta$-actin: 5'-ATG GAT GAC GAT ATC GCT GCG-3' (forward) and 5'-CAG GGT CAG GAT GCC TCT CTT-3' (reverse); cyclin D1: 5'-TGC ATC TAC ACT GAC AAC TCT AT-3' (forward) and 5'-GCA TTT TGG AGA GGA AGT GTT C-3' (reverse); cyclin E: 5'-TGA AAT TGG TGT CGG TGC CTA T-3' (forward) and 5'-TGC TCC TCC ATT AGG AAC TCT CAC-3' (reverse); cyclin-dependent kinase 2 (CDK2): 5'-CTT AAG AAA ATC CGG CTC GAC-3' (forward) and 5'-ATC CAG CAG CTT GAC GAT GTT A-3' (reverse); CDK4: 5'-GAC TCC CAC AAC ATC CAG ACC-3' (forward) and 5'-ACT CGG AGG AGG AGA AAT CCT-3' (reverse); ERa: 5'-CTA AGA AGA ATA GCC CCG CC-3' (forward) and 5'-CAG ACC AGA CCA ATC ATC AGG-3' (reverse); ER $\beta$ : 5'-CGA CTG AGC ACA AGC CCA AAT G-3' (forward) and 5'-ACG CCG TAA TGA TAC CCA GAT G-3' (reverse). For RT-PCR, SYBR ${ }^{\circledR}$ Premix Ex Taq ${ }^{\mathrm{TM}}$ (Takara Bio Inc, Dalian, China) was used. Final PCR products were subjected to graded temperature-dependent dissociation to verify that only one product was amplified. Reactions with no RT sample and no template were included as negative controls. Relative quantitative evaluation of target gene levels was performed by the comparative CT (cycle threshold) method $^{[24]}$ and performed in triplicates.

\section{Western blotting}

VSMCs were lysed and equal amounts of protein from each sample were subjected to SDS-PAGE and blotted on PVDF membrane, which was incubated for $2 \mathrm{~h}$ at room temperature with blocking buffer ( $5 \%$ non-fat milk, $0.1 \%$ Tween 20 , in TBS, $\mathrm{pH}$ 7.6) and then probed with primary antibodies overnight at $4{ }^{\circ} \mathrm{C}$. After incubation with the appropriate secondary antibodies, the immunoreactive band was detected by an ECL Western blotting detection system (GE Healthcare, Bucks, UK) and subsequently photographed by a LAS-3000 luminescent image system (Fujifilm, Tokyo, Japan).

\section{Receptor binding assays}

For ER binding assay, an appropriate amount of estrogen receptor $\alpha / \beta(E R a / \beta)$ was loaded into each well of an Isoplate $^{\mathrm{TM}}$ (PerkinElmer, Boston, MA, USA) containing the assay buffer $\left[10 \%\right.$ glycerol $(v / v), \mathrm{NaH}_{2} \mathrm{PO}_{4} 25 \mathrm{mmol} / \mathrm{L}, \mathrm{MgCl}_{2} 0.5$ $\mathrm{mmol} / \mathrm{L}$, DTT $1 \mathrm{mmol} / \mathrm{L}$, edetic acid $1 \mathrm{mmol} / \mathrm{L}$, CHAPS 5 mmol/L, aprotinin $2 \mathrm{mg} / \mathrm{L}$ and leupeptin $100 \mu \mathrm{mol} / \mathrm{L}]$ followed by addition of $\left[{ }^{3} \mathrm{H}\right]$ estradiol $(140 \mathrm{Ci} / \mathrm{mmol}, 5 \mathrm{nmol} / \mathrm{L}$; PerkinElmer). Various concentrations of $\mathrm{E}_{2}$ were added thereafter and incubated overnight at $4{ }^{\circ} \mathrm{C}$. Twenty-five $\mu \mathrm{L}$ of hydroxyapatite $(25 \%, v / v)$ was added to each well the next morning and the plates were gently agitated twice for $5 \mathrm{~min}$ each. Following centrifugation for $3 \mathrm{~min}$ at $2500 \mathrm{r} / \mathrm{min}\left(4^{\circ} \mathrm{C}\right)$, the supernatant was decanted and $100 \mu \mathrm{L}$ of assay buffer was added to each well. This washing procedure was repeated twice before the addition of $150 \mu \mathrm{L}$ scintillation liquid (PerkinElmer), gentle agitation of the plates to resuspend hydroxyapatite and measurement of radioactivity with a MicroBeta counter (PerkinElmer).

For peroxisome proliferator-activated receptor $\gamma$ (PPAR $\gamma$ ) binding assay, biotinylated PPRE was mixed with the assay buffer containing fish sperm DNA (Shanghai Sangon Biotechnology, Shanghai, China) and $4 \mathrm{mg}$ streptavidin-coated microbeads (GE Healthcare) in a conical polypropylene centrifuge tube, and incubated overnight at $4{ }^{\circ} \mathrm{C}$. The mixture was centrifuged for $10 \mathrm{~min}$ at $2500 \mathrm{r} / \mathrm{min}$. The supernatant was then removed followed by washing three times with $10 \mathrm{~mL}$ assay buffer. Reaction solution $(10 \mathrm{~mL})$ containing $700 \mu \mathrm{g}$ PPAR $\gamma$ extract protein, $47 \mu \mathrm{g}$ retinoid $X$ receptor a (RXRa) extract

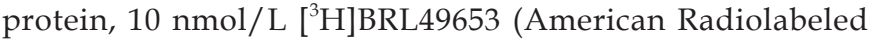
Chemicals, Inc, St Louis, MO, USA), and various concentrations of BRL49653 or farrerol were distributed to each well of an Isoplate ${ }^{\mathrm{TM}}$ (PerkinElmer) and incubated at $4{ }^{\circ} \mathrm{C}$ for $4 \mathrm{~h}$ before counting by a MicroBeta counter (PerkinElmer).

\section{Reporter gene assay}

pERE-Luc reporter $(0.5 \mu \mathrm{g} /$ well of 24 -well plate $)$ or pGL3-Luc (negative control) plasmids were transfected into VSMCs with Lipofectamine $^{\mathrm{TM}}$ (Invitrogen) and the procedure was carried out as directed by the manufacturer. pERE-Luc contains tandems of ERE linked to a downstream luciferase reporter gene. pGL3-Luc is an identical plasmid but without the ERE. The pSV- $\beta$-galactosidase plasmid (pCH110) was co-transfected as an internal control. After transfection for $24 \mathrm{~h}$, cells were treated in conditioned medium and harvested following further $24 \mathrm{~h}$ incubation. Luciferase activity was assayed according to the manufacturer's protocol using the luciferase assay system (Promega, Madison, WI, USA). Relative luciferase units (RLU) normalized to transfection efficiency were calculated as the ratio of luciferase activity to $\beta$-galactosidase.

Gal-ERa and Gal-ER $\beta$ were constructed by transferring the coding sequences for the ligand-binding domain (LBD) of ERa (amino acids 282-595) or ER $\beta$ (amino acids 234-530) to yeast transcription activator protein Gal4, respectively. Gal-ERa or Gal-ER $\beta$, together with the $5 \times$ UAS-Luc reporter and pSV- $\beta$ galactosidase plasmids, were co-transfected into HEK293 cells according to the manufacturer's instructions. Luciferase activity and $\beta$-galactosidase activity were determined as described above.

\section{Statistical analysis}

Results are expressed as mean \pm SEM. Statistical analysis was performed using one-way analysis of variance (ANOVA). The inter-group comparisons (post hoc analysis) among the data with equal variances were made by the LSD method, while Tamhane's T2 method was used for the data with unequal variances. A $P$ value of less than 0.05 is considered significant.

\section{Results}

Farrerol inhibits FBS-induced VSMC proliferation and DNA synthesis

In this study, we first investigated the effect of farrerol on the proliferation of VSMCs using the MTT assay. When growth-arrested cells were treated with farrerol $(0.3,1,3$, and 
$10 \mu \mathrm{mol} / \mathrm{L}$ ) in the presence of $0.1 \% \mathrm{FBS}$, no significant difference was observed in cell viability (Figure 2A, left panel), suggesting that farrerol did not show significant cytotoxicity up to $10 \mu \mathrm{mol} / \mathrm{L}$. The absence of cytotoxicity was further confirmed with a trypan blue exclusion assay (data not shown). However, we found that $5 \%$ FBS treatment led to a 2.65-fold increase in VSMC proliferation, while incubation of the cells with farrerol for $2 \mathrm{~h}$ prior to FBS stimulation reduced cell proliferation in a dose-dependent manner (Figure 2A, right panel). The influence of farrerol on DNA synthesis was also studied: BrdU incorporation was markedly increased in VSMCs following exposure to 5\% FBS for $48 \mathrm{~h}$, indicative of elevated DNA synthesis; this effect was abolished by pretreatment of VSMCs with farrerol in a dose-dependent manner and the complete blocking was achieved at the highest concentration $(10 \mu \mathrm{mol} / \mathrm{L})$ used (Figure $2 \mathrm{~B})$.
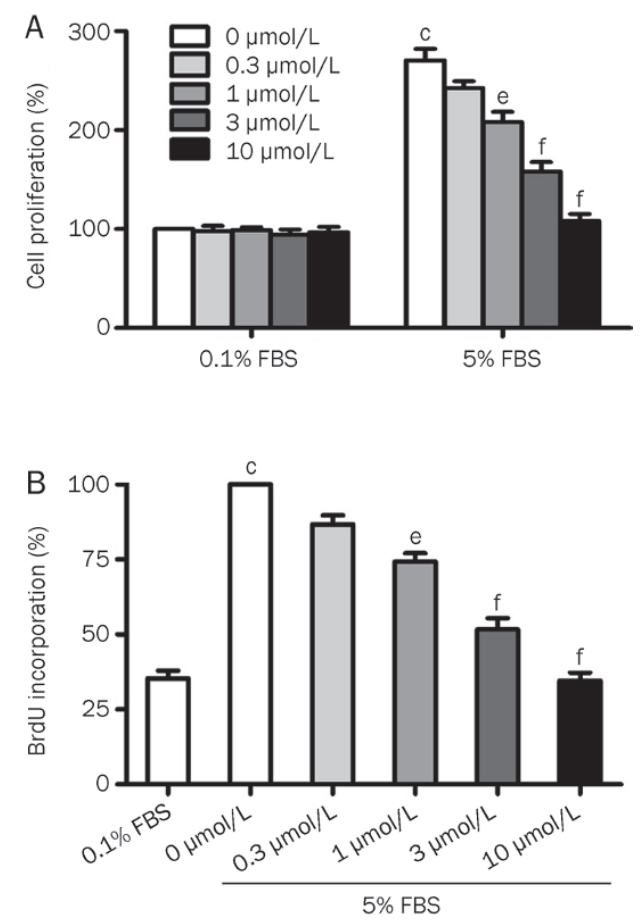

Figure 2. Effects of farrerol on FBS-induced proliferation and DNA synthesis in VSMCs. A, proliferation was measured by the MTT assay in the absence (left) or presence (right) of 5\% FBS. Relative proliferation (\%) was displayed using untreated control cells as a standard $(n=6)$. B, DNA synthesis was measured by BrdU incorporation. The left part shows BrdU incorporation of quiescent and FBS-stimulated VSMCs. On the right side, a concentration-dependent decrease of BrdU incorporation in farreroltreated VSMCs is shown $(n=6)$. Values are presented as mean \pm SEM. ${ }^{\mathrm{c}} P<0.01$ vs control; ${ }^{\mathrm{e}} P<0.05,{ }^{\mathrm{f}} P<0.01$ vs FBS induction.

Farrerol arrests FBS-stimulated VSMCs in $G_{1}$ phase and abrogates cell cycle protein transcription

Proliferative cells pass through several cell cycle checkpoints, mainly the $G_{1}$ to $S$ and $G_{2}$ to $M$ transitions. The former check- point is considered to be the most important step in DNA replication. Accordingly, flow cytometric assessment was performed to determine the effect of farrerol on cell cycle progression. As shown in Figure 3, the percentage of $\mathrm{G}_{0} / \mathrm{G}_{1}$ or $S$ phase cells in the 5\% FBS-stimulated group were $59.32 \% \pm 2.73 \%$ and $18.30 \% \pm 2.62 \%$, respectively. Farrerol at concentrations of 3 and $10 \mu \mathrm{mol} / \mathrm{L}$ effectively increased the proportion of cells in the $G_{0} / G_{1}$ phase and simultaneously decreased the $S$ phase cell population.
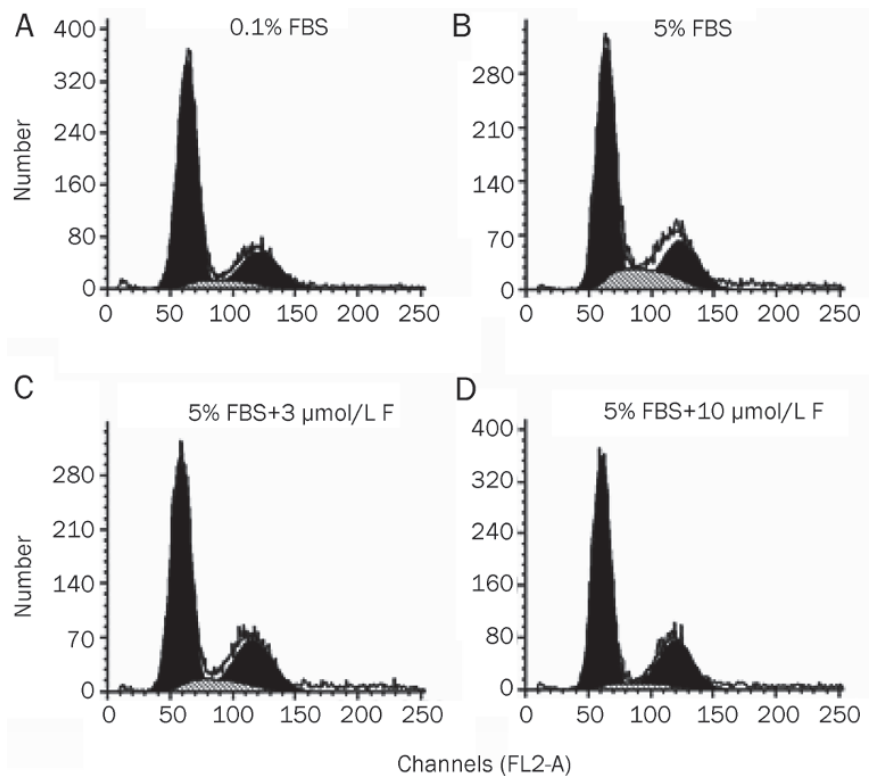

$E$

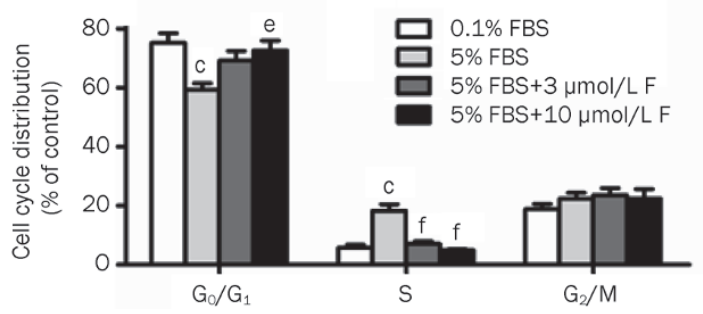

Figure 3. Cell cycle distribution of (A) quiescent and (B) FBS-stimulated VSMCs. $C$ and D show VSMCs treated with $3 \mu \mathrm{mol} / \mathrm{L}$ and $10 \mu \mathrm{mol} / \mathrm{L}$ farrerol $(F)$, respectively, in the presence of FBS. It demonstrates farrerolinduced cell cycle arrest at the $G_{0} / G_{1}$ phase. $G_{0} / G_{1}$ phase is represented by the first peak, $S$ phase in diagonal and $G_{2} / M$ by the second peak. $E$, results are expressed as a percentage of the total number of cells in $G_{0} / G_{1}, S$, or $G_{2} / M$ phases of the cell cycle. Values are presented as mean \pm SEM. ${ }^{c} P<0.01$ vs control; ${ }^{e} P<0.05,{ }^{f} P<0.01$ vs FBS induction.

Then, we examined the mRNA levels of cell cycle-related proteins using real-time PCR to determine whether farrerol induced changes in this pathway. The results were analyzed by the comparative CT method. Treatment with farrerol not only produced a significant down-regulation in cyclin D1 and E gene transcription, but also markedly decreased the expression of CDK2 and CDK4 genes (Figure 4A). 
A

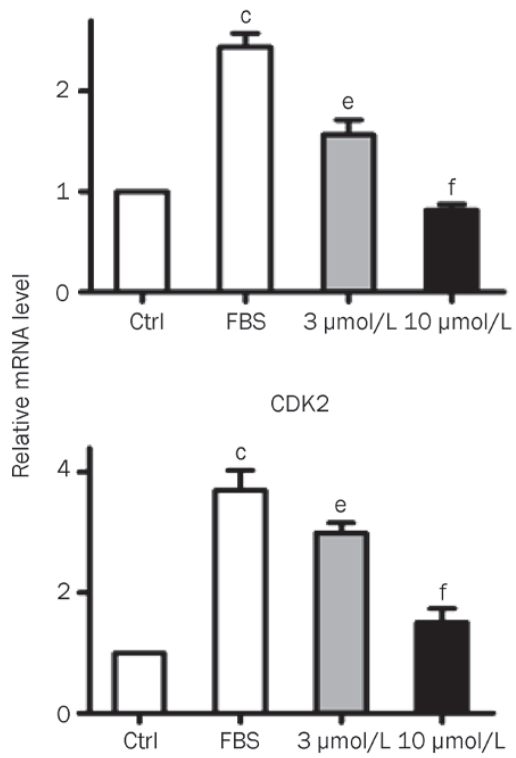

Cyclin E
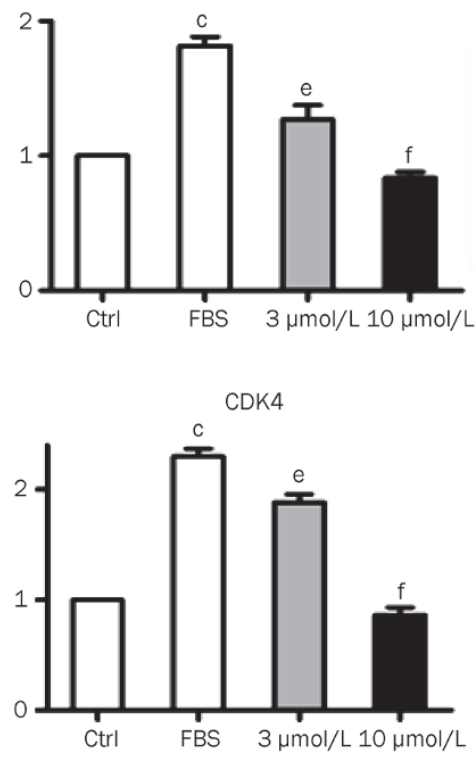

B

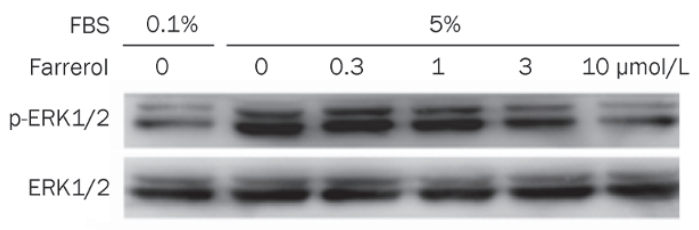

Figure 4. Effects of farrerol on FBS-induced cell cycle protein transcription and ERK1/2 activation in VSMCs. (A) The mRNA levels of cyclin D1, cyclin E, CDK2 and CDK4 were measured by real-time RT-PCR. $\beta$-actin was used as an internal control $(n=4)$. Values are presented as mean \pm SEM. ${ }^{\circ} P<0.01$ vs control (Ctrl); ${ }^{e} P<0.05,{ }^{f} P<0.01$ vs FBS induction. (B) VSMCs were treated with farrerol for $2 \mathrm{~h}$ prior to $\mathrm{FBS}(5 \%)$ stimulation for $15 \mathrm{~min}$. Whole cell lysates were prepared and subsequently used for detection of $\mathrm{p}$-ERK1/2 and ERK1/2 by Western blot.

Farrerol suppresses FBS-induced ERK1/2 phosphorylation in vSMCs

It was reported that ERK1/2 activation plays a critical role in the proliferation of VSMCs ${ }^{[21]}$. Inhibition of this signaling protein proved to be a useful method for preventing intimal hyperplasia ${ }^{[25]}$. Therefore, we examined the effect of farrerol on ERK1/2 activation and the results indicate that exposure of VSMCs to FBS for 15 min enhanced ERK1/2 phosphorylation considerably. Conversely, addition of farrerol dose-dependently abrogated ERK1/2 activation in FBS-stimulated VSMCs: at a concentration of $10 \mu \mathrm{mol} / \mathrm{L}$, farrerol completely blocked the phosphorylation of ERK1/2 (Figure 4B).

\section{Farrerol is a functional ER $\beta$ ligand in VSMCs}

To evaluate the possible role of ER in farrerol-induced antimitogenic activity, we first evaluated the expression of ERa and ER $\beta$ by both Western blot analysis and real-time PCR in VSMCs. Figure 5A depicts that protein and mRNA of both ER subtypes were present in the VSMCs derived from female
Sprague-Dawley rats, as reported previously ${ }^{[26]}$.

Thereafter, an ERE-luciferase reporter gene assay was performed to study whether farrerol acts as a phytoestrogen in VSMCs. As shown in Figure 5B, farrerol was able to activate ER transcription from a luciferase reporter gene (pERE-luc) under the control of a promoter containing two copies of the ERE in VSMCs, showing a 2.1-fold induction over control and the efficacy was comparable to that of $E_{2}$. The ERE-driven luciferase activity induced by farrerol was completely blocked by the ERa/ $\beta$ antagonist ICI182,780, but not by the specific ERa antagonist MPP, implying that farrerol may exert its phytoestrogen action via ER $\beta$.

To obtain further evidence that farrerol activates ER $\beta$ directly, a heterologous system was employed. Chimeric protein consisting of the DNA binding domain of Gal4 and ER $\beta$ LBD, but not ERa LBD, responded to farrerol in a transient expression assay in HEK293 cells (Figures 5C and 5D), thereby pointing to a mechanism of direct interaction between farrerol and ER $\beta$ signaling.
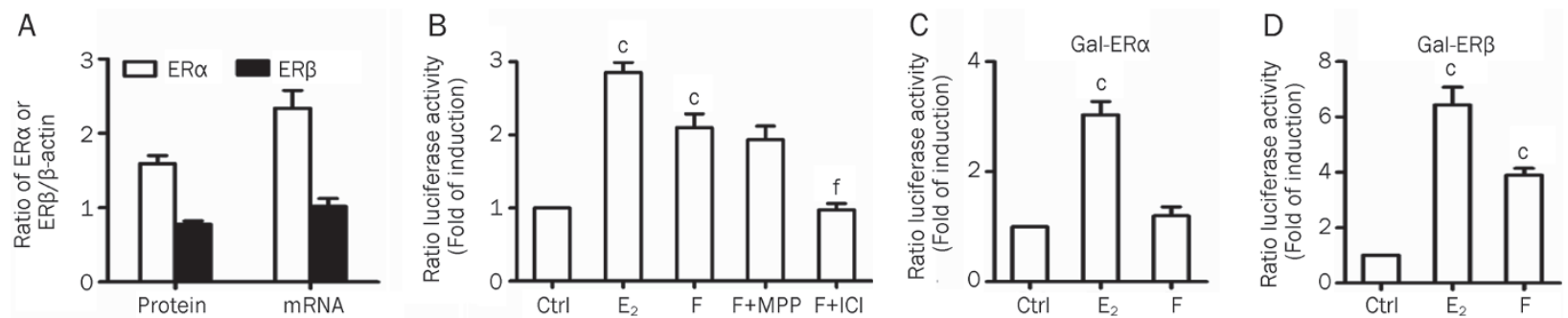

Figure 5. Activation of ER $\beta$-mediated transcription by farrerol in reporter gene assays. A, expression of ER $\alpha$ and ER $\beta$ in VSMCs. Western blot and realtime PCR were performed on VSMCs for ER $\alpha$ and ER $\beta$ protein expression and mRNA quantification. $\beta$-actin was used as an internal control ( $n=3$ ). B, farrerol activates ERE-mediated transcription in VSMCs. Cells cotransfected with pERE-luc and $\beta$-gal expression plasmids were treated with $3 \mu$ mol/L farrerol $(F)$ with or without MPP $(10 \mu \mathrm{mol} / \mathrm{L})$ or ICl182,780 (ICl, $10 \mu \mathrm{mol} / \mathrm{L}) . \mathrm{E}_{2}(100 \mathrm{nmol} / \mathrm{L})$ was used as a positive control. Relative luciferase units (RLU) normalized to transfection efficiency were calculated as the ratio of luciferase activity to $\beta$-galactosidase $(n=3)$. C, fusion protein consisting of ER $\beta$ and Gal4 DBD was activated by farrerol in transfected HEK293 cells $(n=3)$. Values are presented as mean \pm SEM. ${ }^{\mathrm{c}} P<0.01$ vs control $(\mathrm{Ctrl}) ;{ }^{\mathrm{f}} P<0.01 \mathrm{vs}$ farrerol treatment. 
Next, a competitive receptor-binding assay was employed to study binding specificities of farrerol for ERa and ER $\beta$. As shown in Figure 6, the $\mathrm{IC}_{50}$ values of farrerol for ERa and ER $\beta$ were $57 \mu \mathrm{mol} / \mathrm{L}$ and $2.7 \mu \mathrm{mol} / \mathrm{L}$, respectively, implying that farrerol has a higher binding specificity for ER $\beta$ than ERa. Moreover, cross-reactivity check revealed that the binding affinity of farrerol to PPARY is rather weak $\left(\mathrm{IC}_{50}=238 \mu \mathrm{mol} / \mathrm{L}\right.$; Figure 6). These data suggest that farrerol appears to be a selective ER $\beta$ agonist.

\section{Farrerol exerts its action on DNA synthesis mainly via ER $\beta$ in vSMCs}

Previous work has suggested the involvement of ER $\beta$ in the inhibitory effects of estrogen on VSMCs ${ }^{[27]}$. Our results also showed that the selective ER $\beta$ agonist 2,3-bis(4hydroxyphenyl)-propionitrile (DPN, $1 \mu \mathrm{mol} / \mathrm{L}$ ) closely resembled $\mathrm{E}_{2}$ in significantly reducing DNA synthesis in VSMCs (data not shown).

Having established that farrerol is an ER $\beta$ agonist, PHTPP, a specific ER $\beta$ antagonist was chosen to characterize the role of ER $\beta$ in farrerol-mediated effects. Figure 7 shows that blockade of ER $\beta$ signaling by PHTPP noticeably attenuated the inhibitory effect of farrerol on VSMC proliferation while MPP, a specific ERa antagonist was ineffective. Furthermore, neither PPARY antagonist GW9662 nor PPARa antagonist GW6471 was able to reverse the inhibitory effects of farrerol on VSMCs (data not shown). Taken together, the results indicate that ER $\beta$ is involved in farrerol-mediated inhibition on VSMC proliferation.

\section{Discussion}

The development of advanced lesions associated with atherosclerosis and restenosis is highly dependent on VSMC proliferation. Thus, inhibition of VSMC proliferation has become one of the focal points in the prevention of atherosclerosis ${ }^{[3]}$. Farrerol, a naturally occurring flavonoid derivative, is found in various plants and more abundantly in Rhododendron dauricum L. Here we show that farrerol possesses estrogenic properties and could mimic $\mathrm{E}_{2}$ to suppress VSMC proliferation in vitro. We also demonstrate that the effect exerted by farrerol on cell

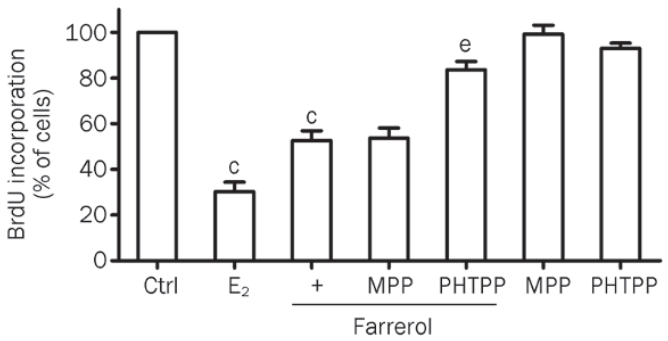

Figure 7. Inhibition on VSMC DNA synthesis by farrerol was reversed by a specific ER $\beta$ antagonist, PHTPP. Cells were treated with or without $3 \mu \mathrm{mol} / \mathrm{L}$ farrerol, in the absence or presence of PHTPP $(5 \mu \mathrm{mol} / \mathrm{L})$ or $\operatorname{MPP}(10 \mu \mathrm{mol} / \mathrm{L}) . \quad \mathrm{E}_{2}(100 \mathrm{nmol} / \mathrm{L})$ was used as a positive control $(n=3)$. Values are presented as mean \pm SEM. ${ }^{c} P<0.01$ vs control (Ctrl); ${ }^{e} P<0.05$ vs farrerol treatment.

cycle involves the participation of ER $\beta$, but not ERa. Our data thus provide a potential molecular target through which farrerol manifests itself as an anti-mitogenic agent.

In this study, we replaced a single growth factor with $5 \%$ FBS to induce cell proliferation. FBS contains a range of growth factors, including platelet-derived growth factor (PDGF), fibroblast growth factor (FGF), transforming growth factor, serotonin, and thrombin ${ }^{[18]}$. It was hoped that this would simulate the multiple factors environment in vivo. Indeed, addition of 5\% FBS to the culture medium resulted in a 2.65 -fold increase in VSMC proliferation that was blocked by farrerol in a concentration-dependent manner (Figure 2).

Cell cycle is a highly regulated process that involves a complex cascade of events. Modulation of expression and function of cell cycle regulatory proteins provides an important approach to the control of cell growth. According to the flow cytometry analysis, farrerol profoundly decreased FBSinduced transition to the $\mathrm{S}$ phase (Figure 3). It is known that the move from $G_{1}$ to $S$ phase is closely linked to the activation of cell cycle regulatory proteins such as $\mathrm{CDKs}^{[28]}$. In particular, the cyclin D1/CDK4 and cyclin E/CDK2 complexes are essential for entering the $S$ phase ${ }^{[28]}$. As shown in Figure 4A, farrerol displayed a potent inhibitory effect on the expression of a number of cell cycle regulatory proteins (cyclin D1, cyclin
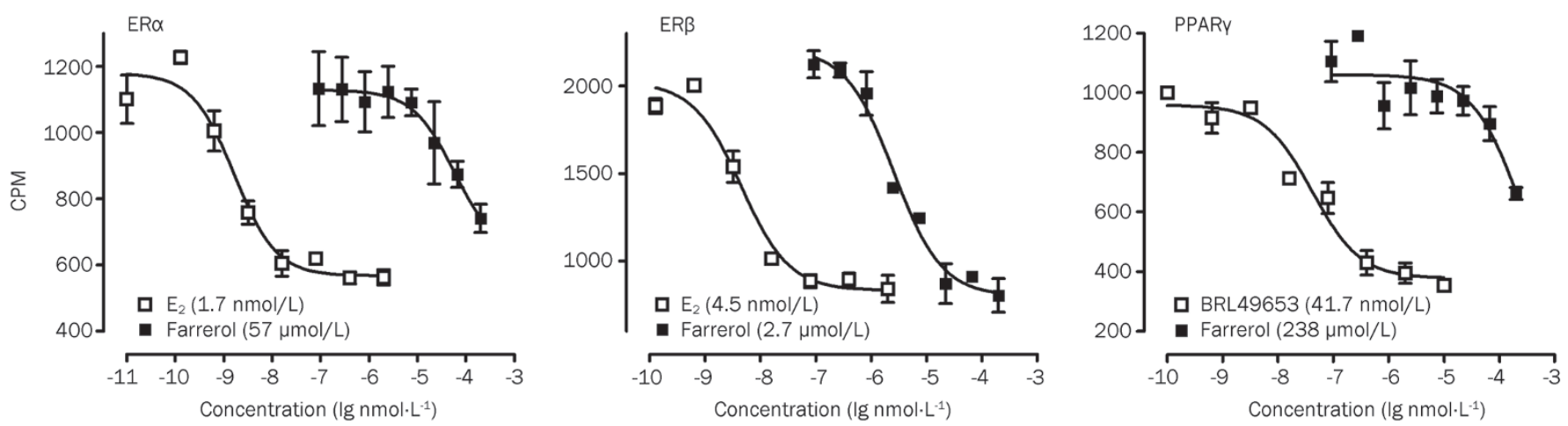

Figure 6. Specificity of farrerol for ER $\beta$. Competitive receptor-binding assay was conducted to assess interaction between radiolabeled ligands and recombinant human ER $\alpha, E R \beta$, and PPARy. Values in parentheses indicate respective $\mathrm{IC}_{50}(\mu \mathrm{mol} / \mathrm{L})$ of farrerol for each receptor. Data are presented as mean \pm SEM. 
$\mathrm{E}, \mathrm{CDK} 2$, and CDK4). It appears that farrerol exerts its action through down-regulation of positive regulators in the cell cycle.

Cell cycle modulators such as cyclin D1 and cyclin E are regulated by ERK1/2 pathway, which plays a crucial role in serum-induced VSMC proliferation ${ }^{[28]}$. After mitogenic stimulation, ERK1/2 is phosphorylated by MEK kinase and enters the nucleus, where it regulates the expression of cell cycle regulators and subsequent DNA synthesis in VSMCs ${ }^{[29]}$. In our study, farrerol significantly decreased FBS-induced phosphorylation of ERK1/2 thereby suggesting that farrerol is a negative effecter for ERK1/2 activation leading to suppression on the expression of cell cycle regulators and eventual growth arrest.

An interesting observation relates to the fact that farrerol interacts directly with $E R \beta$, rather than ERa, in VSMCs. In the ERE-reporter gene assay, farrerol was able to activate transcription from the consensus ERE motifs, while specific induction of Gal-ER $\beta$-mediated transactivation and direct binding to ER $\beta$ confirmed the relationship between this phytoestrogen and ER $\beta$ signaling machinery.

The mechanism by which of estrogens exert inhibitory actions on VSMCs has been intensely investigated following the discovery of a second ER subtype, ER $\beta$. Earlier studies in mice showed that estrogen inhibited VSMC proliferation in the medial area in response to vascular injury in both $\mathrm{ERa}^{[30]}$ and $E R \beta$ knockout mice ${ }^{[31]}$, indicating that both subtypes are responsible for the anti-mitogenic effect observed. Moreover, it was documented that ER $\beta$ was more potent than ERa in inhibiting VSMC proliferation ${ }^{[23,32]}$. Taken together, it seems that ER $\beta$ behaves like a key mediator for estrogen-related vascular protection. Since isoflavones are capable of preferentially inducing ER $\beta$ expression, their beneficial effects on the cardiovascular system of postmenopausal women may be mediated via this pathway ${ }^{[33,34]}$.

In conclusion, our study provides new experimental evidence supporting the postulated property of farrerol as a functional phytoestrogen capable of inhibiting FBS-induced VSMC proliferation. The effects exerted by farrerol are cell cycle related and ER $\beta$ specific. Elucidation of underlying mechanisms of action may offer insights into a possible molecular target relevant to the therapeutic use of this class of natural products, represented by farrerol, in certain cardiovascular diseases, where excess proliferation plays a pivotal pathological role.

\section{Acknowledgements}

We are indebted to Drs Tao HE and Dale E MAIS for valuable comments on this manuscript. The study was supported in part by grants from the Ministry of Science and Technology of China (No 2009ZX09302-001) and Shanghai Municipality Government (№ 08DZ2291300 and 09DZ2291200).

\section{Author contribution}

Qun-yi LI, Li CHEN, and Meng ZHANG performed experiments; Qun-yi LI, Li CHEN, Yan-hui ZHU, Yi-ping WANG, and Ming-wei WANG analyzed the data; Qun-yi LI, Li CHEN, and Ming-wei WANG wrote the paper.

\section{References}

1 Rivard A, Andres V. Vascular smooth muscle cell proliferation in the pathogenesis of atherosclerotic cardiovascular diseases. Histol Histopathol 2000; 15: 557-71.

2 Andres V, Castro C. Antiproliferative strategies for the treatment of vascular proliferative disease. Curr Vasc Pharmacol 2003; 1: 85-98.

3 Grodstein F, Stampfer MJ, Manson JE, Colditz GA, Willett WC, Rosner $\mathrm{B}$, et al. Postmenopausal estrogen and progestin use and the risk of cardiovascular disease. N Engl J Med 1996; 335: 453-61.

4 Dubey RK, Gillespie DG, Mi Z, Rosselli M, Keller PJ, Jackson EK. Estradiol inhibits smooth muscle cell growth in part by activating the cAMP-adenosine pathway. Hypertension 2000; 35: 262-6.

5 Akishita M, Ouchi Y, Miyoshi H, Kozaki K, Inoue S, Ishikawa M, et al. Estrogen inhibits cuff-induced intimal thickening of rat femoral artery: effects on migration and proliferation of vascular smooth muscle cells. Atherosclerosis 1997; 130: 1-10.

6 Rossouw JE, Anderson GL, Prentice RL, LaCroix AZ, Kooperberg C, Stefanick ML, et al. Risks and benefits of estrogen plus progestin in healthy postmenopausal women: principal results from the Women's Health Initiative randomized controlled trial. JAMA 2002; 288: 32133.

7 Anderson GL, Limacher M, Assaf AR, Bassford T, Beresford SA, Black $\mathrm{H}$, et al. Effects of conjugated equine estrogen in postmenopausal women with hysterectomy: the Women's Health Initiative randomized controlled trial. JAMA 2004; 291: 1701-12.

8 Hsia J, Langer RD, Manson JE, Kuller L, Johnson KC, Hendrix SL, et al. Conjugated equine estrogens and coronary heart disease: the Women's Health Initiative. Arch Intern Med 2006; 166: 357-65.

9 Manson JE, Allison MA, Rossouw JE, Carr JJ, Langer RD, Hsia J, et al. Estrogen therapy and coronary-artery calcification. N Engl J Med 2007; 356: 2591-602.

10 Dubey RK, Gillespie DG, Imthurn B, Rosselli M, Jackson EK, Keller PJ. Phytoestrogens inhibit growth and MAP kinase activity in human aortic smooth muscle cells. Hypertension 1999; 33: 177-82.

11 Grainger DJ, Metcalfe JC. Tamoxifen: teaching an old drug new tricks? Nat Med 1996; 2: 381-5.

12 Cerquetani E, Vitale C, Mercuro G, Fini M, Zoncu S, Rosano GM. Comparative vascular effects of hormone replacement therapy and raloxifene in women at increased cardiovascular risk. Gynecol Endocrinol 2004; 18: 291-8.

13 Sacks FM, Lichtenstein A, Van Horn L, Harris W, Kris-Etherton P, Winston M. Soy protein, isoflavones, and cardiovascular health: an American Heart Association Science Advisory for professionals from the Nutrition Committee. Circulation 2006; 113: 1034-44.

14 Cassidy A, Hooper L. Phytoestrogens and cardiovascular disease. J Br Menopause Soc 2006; 12: 49-56.

15 Kim SY, Jin YR, Lim Y, Kim JH, Cho MR, Hong JT, et al. Inhibition of PDGF $\beta$-receptor tyrosine phosphorylation and its downstream intracellular signal transduction in rat aortic vascular smooth muscle cells by kaempferol. Planta Med 2005; 71: 599-603.

16 Ibarra M, Perez-Vizcaino F, Cogolludo A, Duarte J, Zaragoza-Arnaez F, Lopez-Lopez JG, et al. Cardiovascular effects of isorhamnetin and quercetin in isolated rat and porcine vascular smooth muscle and isolated rat atria. Planta Med 2002; 68: 307-10.

17 Cao Y, Lou C, Fang Y, Ye J. Determination of active ingredients of Rhododendron dauricum $L$ by capillary electrophoresis with electrochemical detection. J Chromatogr A 2002; 943: 153-7.

18 Peng YY, Liu FH, Ye JN. Determination of bioactive flavonoids 
in Rhododendron dauricum L by capillary electrophoresis with electrochemical detection. Chromatographia 2004; 60: 597-602.

19 Cao Y, Chu Q, Ye J. Chromatographic and electrophoretic methods for pharmaceutically active compounds in Rhododendron dauricum. J Chromatogr B Analyt Technol Biomed Life Sci 2004; 812: 231-40.

20 Rodriguez A, Fortuno A, Gomez-Ambrosi J, Zalba G, Diez J, Fruhbeck G. The inhibitory effect of leptin on angiotensin II-induced vasoconstriction in vascular smooth muscle cells is mediated via a nitric oxidedependent mechanism. Endocrinology 2007; 148: 324-31.

21 Sasu S, LaVerda D, Qureshi N, Golenbock DT, Beasley D. Chlamydia pneumoniae and chlamydial heat shock protein 60 stimulate proliferation of human vascular smooth muscle cells via toll-like receptor 4 and p44/p42 mitogen-activated protein kinase activation. Circ Res 2001; 89: 244-50.

22 Pizarro JG, Yeste-Velasco M, Esparza JL, Verdaguer E, Pallas M, Camins A, et al. The antiproliferative activity of melatonin in $\mathrm{B} 65$ rat dopaminergic neuroblastoma cells is related to the downregulation of cell cycle-related genes. J Pineal Res 2008; 45: 8-16.

23 Watanabe T, Akishita M, Nakaoka T, Kozaki K, Miyahara Y, He H, et al. Estrogen receptor $\beta$ mediates the inhibitory effect of estradiol on vascular smooth muscle cell proliferation. Cardiovasc Res 2003; 59 : 734-44.

24 Livak KJ, Schmittgen TD. Analysis of relative gene expression data using real-time quantitative PCR and the $2^{-\triangle \Delta C T}$ method. Methods 2001; 25: 402-8.

25 Nelson PR, Yamamura S, Mureebe L, Itoh H, Kent KC. Smooth muscle cell migration and proliferation are mediated by distinct phases of activation of the intracellular messenger mitogen-activated protein kinase. J Vasc Surg 1998; 27: 117-25.

26 Yoon BK, Oh WJ, Kessel B, Roh CR, Choi D, Lee JH, et al. 17ß-Estradiol inhibits proliferation of cultured vascular smooth muscle cells induced by lysophosphatidylcholine via a nongenomic antioxidant mechanism. Menopause 2001; 8: 58-64.

27 Geraldes P, Sirois MG, Tanguay JF. Specific contribution of estrogen receptors on mitogen-activated protein kinase pathways and vascular cell activation. Circ Res 2003; 93: 399-405.

28 Wei GL, Krasinski K, Kearney M, Isner JM, Walsh K, Andres V. Temporally and spatially coordinated expression of cell cycle regulatory factors after angioplasty. Circ Res 1997; 80: 418-26.

29 Adam RM, Borer JG, Williams J, Eastham JA, Loughlin KR, Freeman MR. Amphiregulin is coordinately expressed with heparin-binding epidermal growth factor-like growth factor in the interstitial smooth muscle of the human prostate. Endocrinology 1999; 140: 5866-75.

30 lafrati MD, Karas RH, Aronovitz M, Kim S, Sullivan TR Jr, Lubahn $\mathrm{DB}$, et al. Estrogen inhibits the vascular injury response in estrogen receptor $\alpha$-deficient mice. Nat Med 1997; 3: 545-8.

31 Karas RH, Hodgin JB, Kwoun M, Krege JH, Aronovitz M, Mackey W, et al. Estrogen inhibits the vascular injury response in estrogen receptor $\beta$-deficient female mice. Proc Natl Acad Sci U S A 1999; 96: 15133-6.

32 Lindner V, Kim SK, Karas RH, Kuiper GG, Gustafsson JA, Mendelsohn ME. Increased expression of estrogen receptor- $\beta$ mRNA in male blood vessels after vascular injury. Circ Res 1998; 83: 224-9.

33 Crisafulli A, Altavilla D, Marini H, Bitto A, Cucinotta D, Frisina N, et al. Effects of the phytoestrogen genistein on cardiovascular risk factors in postmenopausal women. Menopause 2005; 12: 186-92.

34 Goodman-Gruen D, Kritz-Silverstein D. Usual dietary isoflavone intake is associated with cardiovascular disease risk factors in postmenopausal women. J Nutr 2001; 131: 1202-6. 